\title{
A War of Words
}

\section{The Cultural Meanings of the First World War in Britain and Germany}

\author{
Mark Hewitson
}

To the critic Alfred Kazin, conflicts before the Second World War had regularly been described in 'traditional literary ways'. ${ }^{1}$ Likewise, for the historian Jay Winter, it was only Hiroshima and Auschwitz that had - in Julia Kristeva's words - 'undermined the very symbols through which meaning - any meaning - could be attached to the "cataclysm" of war'. ${ }^{2}$ Before that point in time, religious or spiritual redemption had appeared possible, present even in the anti-war novels of Henri Barbusse, Ernest Hemingway and Erich Maria Remarque. 3 The heroic tropes of nineteenth-century art and literature helped some contemporaries to contextualize, explain and justify the Great War. ${ }^{4}$ For others, although heroism had been discredited, writing seemed to allow combatants and civilians to look for meaning and make sense of the conflict. Whereas silence was associated with a transfixed state of fear, meaninglessness or mourning, words offered solace and signification.

Here, I examine the ways in which written accounts of war, rather than visual images, served to challenge popular expectations and break taboos. ${ }^{5}$ Since the mid-nineteenth century, various means had been used to bring 'news' of conflicts to public attention. Newspaper reports had been eagerly awaited by readers - above all in the educated, middling strata of towns - during the Revolutionary and Napoleonic Wars. ${ }^{6}$ Their readership had increased markedly in size during the nineteenth century. War correspondents such as William Howard Russell had become famous for their frank and adventurous descriptions of the Crimean War and the Wars of German Unification.7 Their articles were complemented by photographs, which had been taken of the Crimean and American Civil Wars, and lithographs of conflicts, which had been published by masscirculation periodicals such as the Gartenlaube and The Illustrated London News. ${ }^{8}$ They were also informed by eye-witness accounts and letters from the fighting front, which grew dramatically in number during the Franco-German War. The Feldpost of the North German Confederation delivered 89,659,000 letters and postcards between 16 July 1870 and 31 March 1871, compared to 30,000 or so letters carried by the Prussian field post in 1866. ${ }^{9}$ According to Bernd Ulrich, 28,000,000,000 postcards and letters were sent to and from the front during the First World War. ${ }^{10}$ These means of passing on news competed

and overlapped with - and contradicted - each other in the unprecedentedly intensive and severe fighting of the First World War, as a majority of men - 56.6 million in the major European powers alone (Austria-Hungary, Germany, Turkey, Great Britain, France, 
Russia and Italy) - marched off to battle. ${ }^{11}$ These men were able to relay many of their experiences directly to their families and communities on the home front, creating a disparate 'public' which was closer to the fighting and more critical of official accounts, newspaper reportage, and artistic and literary representations of the war. ${ }^{12}$

With hindsight, Alan Kramer's 'dynamic of destruction' seems to entail a predictable escalation of ideas and events, as individual powers used technology and appealed for a defence of territory, statehood and culture within an international 'anarchy' or, at least, a diplomatic and military sphere which was inadequately controlled by diplomatic conventions and international law. ${ }^{13}$ Many historians accept that a fundamental transformation occurred, irrespective of whether it was made sense of through the lens of private memories, public remembrance, residual patriotism, persisting religious beliefs, or local and family ties, which helped returning soldiers reintegrate after 1918.14 They diverge, however, in their identification and evaluation of the precise mechanisms, processes and decisions which brought the transformation into being. In other words, scholars disagree about both the causes and the extent of any social and cultural shift from a pre-war belle époque to a post-war 'waste land' (T. S. Eliot). How important were soldiers' experiences of combat (Alexander Watson, Aribert Reimann), how closely connected were these experiences to the products of modern culture (Modris Eksteins, George Mosse), what role did culture play in creating or consolidating a rupture between the old, pre-war regime (Arno Mayer) and an ironic or fragmented new one, at once championed and criticized by the artists and writers of Modernism (Paul Fussell)? 15

Much recent historiography has qualified Fussell's and Ekstein's overlapping notions of the First World War as a cultural caesura. Gertrude Stein's and Ernest Hemingway's idea of a 'lost generation', and British and German variants on this theme, have long been subject to criticism. ${ }^{16}$ Likewise, Eric Leed's identification of a separate, disillusioned 'community of the trenches', alienated from and disgusted by the perceived callousness, compromises and corruption of the home front has been widely challenged. ${ }^{17} \mathrm{~J}$. G. Fuller was the first of many to stress citizens-as-soldiers' persisting ties to their homes and to civilian culture ${ }^{18}$ Benjamin Ziemann, amongst others, has investigated such ties in Germany. ${ }^{19}$ Most soldiers seemed glad to go back to domestic life after 1918 (Joanna Bourke) and went on defending the necessity of war, rather than turning to pacifism (Sonja Levsen). ${ }^{20}$ Correspondingly, scholars have been keen to reassess the representativeness of disenchanted high-brow writers, separating their opinions from those of ordinary veterans (Deborah Cohen), memoirists (Brian Bond), and middle-brow authors (Hugh Cecil, Rosa Marie Bracco), many of whom remained patriotic and dutiful. ${ }^{21}$ 'War literature' - a category or, even, separate genre including memoirs, correspondence, novels and poetry - and veterans' memories of the First World War were heterogeneous and anachronistic, conditioned by the vagaries of the post-war era. ${ }^{22}$ 'War stories have always both reflected and illuminated the workings of the society within which they were written,' claims Janet Watson. ${ }^{23}$

Soldiers' accounts of their experiences and memories, public commemoration, memoirs, histories, correspondence, literature, theatre, film, caricature, painting and photography provided competing impressions of the First World War, refracted through the filters of high and popular culture and affected by commentators' social position and 
party affiliation, together with their perception of political stability and collapse, and victory and defeat. All these factors played a contested part in the transformation of postwar Europe. ${ }^{24}$ My purpose here is to investigate the ramifications of combatants' letters and diaries, many of which are strikingly similar to contemporaneous and later works of literature. ${ }^{25}$ Given that combatants' own letters home had already exposed the realities of modern warfare, what difference did literary portrayals of the same experiences make to the enduring cultural legacy of the war? A comparison of British and German accounts of the conflict helps to answer this question because such accounts converged in most respects, except in relation to the outcome of the war. ${ }^{26}$

\section{Myth and Propaganda}

The First World War was welcomed by journalists, academics, writers and artists throughout Europe. ${ }^{27}$ In Germany, the 'Aufruf an die Kulturwelt' by 93 representatives of German cultural life set the tone, with Karl Scheffler, the editor of Kunst and Künstler, typical of many as he predicted that the German Volk would come to dominate the spiritual realm, not merely the political one, after a victorious military campaign. ${ }^{28}$ Many soldiers were moved by such rhetoric. The 'only thing that inspires and uplifts one is love for the German fatherland and the desire to fight and risk all for emperor and empire,' wrote Walter Roy, a student of medicine, on 14 November 1914. ${ }^{29}$ Even later vociferous opponents of the war like Ernst Toller volunteered to fight. As Hans Richter noted, the founding members of the Dada movement had decided initially that they should meet two years later to work out what could be done about the war, since there was no point doing so in $1914 .{ }^{\circ}$ In Britain, 'No-German' and 'All-English' concerts were organized by conductors such as Thomas Beecham and 'Junkerism in Art' was decried by The Times. War novels quickly became the most popular form of literature, reviewed in batches in the press by 1915, and Rupert Brooke, who sold 300,000 copies of his Collected Poems, became the most popular poet during and after the war. ${ }^{31}$ Such works reminded contemporaries that it was their 'great privilege', as one soldier noted on 1 October 1914, 'to save the traditions of all the centuries behind us'.$^{32}$ In these circumstances of popular patriotism and paranoia (informants, spies, atrocity stories), governments initially had to do little more than coordinate private initiatives. Nevertheless, the state of siege imposed in Germany at the start of the war and the Defence of the Realm Act passed on 8 August 1914 in Britain ensured that the authorities retained control of 'propaganda', as public information came to be known. 33

Propaganda took a similar form, with individual variations, in most western and central European combatant states. It began unsystematically and amateurishly, but had become much more organised by the end of the war. ${ }^{34}$ In the United Kingdom, the word 'propaganda' did not, in the words of one MP and minister, make 'a pleasant sound in English ears' ${ }^{35}$ A War Propaganda Bureau was set up under Charles Masterton in AugustSeptember 1914, but it was kept secret and it was not responsible for either domestic

propaganda or propaganda in Germany and Austria-Hungary, only that in neutral countries. There was no Department of Information until February 1917. A paper like The 
Times was prosecuted only once during the entire war. In Germany, censorship in theory was more organised at an earlier stage under the formal control of regional military commanders (according to the 1851 Law of Siege), but in fact few publications were banned..$^{6}$ Even the SPD's Vorwärts was published throughout the conflict: when it called for a general strike in January 1918, its publication was suppressed for only three days.

Three responses to government and press campaigns stand out, underpinned by varying levels of xenophobia: the dissemination of atrocity stories; the espousal of 'national values' and development of stereotypes; and the adoption of expansionist and aggressive war aims. Atrocity stories were examined in detail at the time by the anti-war British Radical MP Arthur Ponsonby and published in a famous book on Falsehood in War-Time in 1928.37 The MP collected press cuttings on the most famous stories in order to show the degree of credulity of all involved, caught up in a type of collective psychosis. British stories focused on the Kaiser, who was a barbarian chief, a lunatic, monster, Judas and criminal, according to the Daily Mail in September 1914, and a criminal responsible for murder, rape and drowning, according to the Daily Express..$^{8}$ Most early stories in the United Kingdom centred on Belgium, the invasion of which supposedly defenceless country had been Britain's official reason for entering the war: for example, a carter's daughter of 13, allegedly raped and bayoneted; a young boy whose hands were chopped off after he had failed to direct soldiers; or the Belgians whose breasts and hands had been cut off and who were being cared for in Ramsgate hospital. ${ }^{39}$ The story was denied by the hospital itself, just as others were disproved by US observers who interviewed Belgian refugees, yet they were still believed well after the war. $4^{\circ}$

Spurred on by such stories of atrocity, public opinion in most powers - especially in Britain, France and Germany - quickly began to demonise their principal enemies, developing peacetime stereotypes and making them more extreme. In Germany, this process of national identification was associated with the so-called 'ideas of 1914', born out of the unexpected unity of the 'August days'. 'German values' supposedly included courage, fortitude, strength, dependability, piety, introspection, depth, masculinity and mysticism. ${ }^{41}$ Against German 'heroes', in the phrase of the economist Werner Sombart, who wrote the best-known treatise on the subject, were to be pitted British 'traders'.42 Britons' images of their German enemy were similarly Manichean, focusing on arrogance, barbarity, angularity, Prussianism, bullying, inhumanity, cleverness, and many other traits, which were ascribed in order to distinguish their own 'civilisation' or habits of decency and fair play. 43

The existence of such demonic images sustained expansionist war aims predicated on the idea of the total defeat of the enemy, which conservatives and right-wing nationalists proved unwilling to give up, despite the scale of the slaughter. 44 Indeed, as the number of casualties mounted, it was difficult for leaders from different political camps to justify the killing other than by promising the defeat of the opposing 'aggressor'. 45 These views, which were typical of the home front (although far from uniform), differed markedly from those of soldiers, who could see no point in a war of aggression or complete victory and who had come to view their opponents as victims like themselves, knowing that the real atrocities were not being carried out on civilians, but on soldiers by artillery (often their own).46 ' I have followed in the wake of the grim reaper, and have helped to sharpen his sickle as he 
cut mighty swathes from the Vosges to the sea,' wrote Sergeant James Duncan to Reverend Duncan McArthur on 5 September 1918, in what was probably his last letter home: 'When you look back and find that this same harvest has been nurtured by the sons of Christianity and evolution, you will no doubt like myself pause and consider.' 47 Few soldiers wanted to return to the home front, where justifications of war remained dominant, wrote Duncan: 'Do you know what bothered us most of all was the thought of going back to "Blighty" and facing our old pals and our women folk at home.' 48

\section{Letters Home}

The impressions of war passed on to their families by combatants differed from those propagated by the authorities, the press, intellectuals and artists at home. 49 'War is a terrible thing,' wrote one German conscript to his girlfriend on 10 September 1914: 'When one experiences what one has, it is much worse than it is in the newspapers.' 50 Soldiers, after all, faced the prospect of maiming and death. 4.2 million of the 13.2 million men who served in the German army during the First World War were injured, often severely. ${ }^{1}$ According to Jean-Jacques Becker, Germany mobilized 154/1,000 citizens, of whom 30 were killed, and Britain 125/1,ooo, of whom 16 were killed. This meant that 155/1,000 men of fighting age died in Germany and 88/1,000 in Britain (compared to 3/1,000 in the US). $5^{2}$ In the face of such risks, soldiers' impressions varied significantly, describing experiences which were widely but not commonly known. Because of official censorship and the silence of many soldiers at the fighting front - those on the home front only knew a small part of the story, notwithstanding surprisingly unvarnished accounts in letters published by the press. 53 Although it was true that millions of moving and revealing letters did get through army censors, they were often taken to be personal accounts, perhaps limited to the particular conditions experienced by one's own son or husband. 'For most of the world', reflected H. G. Wells's protagonist in Mr Britling Sees It Through (1916), the war 'came as an illimitable, multitude of incoherent, loud, and confusing impressions'.54

Many soldiers only sent the notorious Field Service Postcard, whose formulaic phrases were inclined to optimism or sanitization. 55 As R. E. Vernède recounted, a 'rather nice boy in my platoon ...writes a family letter daily', which always ran:

'Dear Mum and Dad, and dear loving sisters Rosie, Letty, and our Gladys,I am very pleased to write you another welcome letter as this leaves me. dear Mum and Dad and loving sisters, I hope you keeps the home fires burning. Not arf. The boys are in the pink. Not arf. Dear Loving sisters Rosie, Letty, and our Gladys, keep merry and bright. Not arf.'56

'It goes on like that for three pages', recorded Vernède, 'absolutely fixed; and if he has to say anything definite, like acknowledging a parcel, he has to put it in a separate letter not to interfere with the sacred order of things.' 57 Receiving such letters, together with only a handful of carefully selected images of the fighting, those on the home front received a very different impression of war from those in the trenches. 
Vernède himself gave a different impression of the fighting. He was not unusual. Many combatants, particularly middle-class officers but also many working and lower-middleclass soldiers in the ranks, had entered the war in a state of jubilation, feeling it to be a vindication of their national community, a source of adventure, a release from the constraints of pre-war society, with its restrictive moral codes and manners, or even a heroic reaction against the rationality and anonymity of capitalist production..$^{8}$ In fact, war was a mass affair, confronting middle-class sons with conditions in the trenches worse than those in the slums of Glasgow or the Ruhr, and threatening them with 'proletarianisation', even if they were officers, since they had to serve in the same conditions, despite sleeping in their own bunkers. Notwithstanding feelings of loyalty within fighting units, combatants experienced a high turnover of recruits because of injury, disease and death, leaving many with an overwhelming vision of being anonymous cogs in a large and uncontrollable machine. ${ }^{59}$ War had made society appear inescapably 'industrial', disappointing many middle-class participants' earlier hopes of a return to a rural or agrarian idyll, akin to that of medieval knights or Romantic poets. Soldiers like Ernst Jünger, the author of In Stahlgewittern and many other works on the war, felt themselves to be powerless against the new technology of warfare and industrial production, as if men were labouring impossibly against the laws of physics and were only able to cower before artillery, not advance against it heroically. ${ }^{60}$

In the First World War, the majority of combatants seem to have lived - whilst at the front - in constant fear of random death, with 60 percent of deaths caused by artillery compared to less than 10 percent in the Franco-German war in 1870-1. Faced with such conditions, four overlapping sets of responses have been identified. The first was mental and physical breakdown, manifesting itself as mutism and physical disability (especially amongst ordinary soldiers), and as fits of weeping, stuttering, tremors and memory loss (amongst officers, who felt themselves responsible and who were expected to show leadership and fearlessness). ${ }^{61}$ It was 'endlessly exhausting and difficult to be an officer' ('what a responsibility one bears!'), wrote the reserve lieutenant and painter Arthur Schicht in October 1914: 'One must achieve the super-human and strain every nerve.'62 This was the first 'psychiatric' war, with both sides deploying various techniques such as electric shocks, or deprivation of food and sleep, in order to force soldiers to deny or control their symptoms and return to the front. Most combatants talked of their 'nerves'. 'To be able to prove oneself no coward to oneself, will be great, if it comes off: but suppose one finds oneself fail in the test,' wrote Captain Charles Hamilton Sorley in October 1915, one year after he had been due to go up to Oxford: 'I dread my own censorious self in the coming conflict - I also have great physical dread of pain .... Pray that I ride my frisky nerves with a cool and steady hand when the time arrives.'63 Helmut Zschuppe, who had been a philosophy student in Leipzig in July 1914, penned a very similar description in October 1916:

It doesn't do one any good to spend one's time between going on guard every fifth and sixth hour and sleeping in a mud-hole or a half-finished dug-out at the far end of which the air is so bad that a candle won't burn. And after an attack in a trench with bombs and flame-throwers one's very soul 
is seared. By the time I was wounded my nerves were in such a state that I had to make a great effort to control myself even though it didn't hurt. 64

As one soldier put it, writing from the Eastern Front on 20 August 1914, 'Our nerves are overwrought and our senses numbed by the smell of blood.' 65 In the words of another, describing trench warfare and artillery barrages on the same front, "the spectacle is a bit harsh for delicate nerves'. ${ }^{66}$ 'One must have nerves of iron here to meet the horrors of war with the necessary cold blood,' wrote a friend to the same family: 'I myself don't master my own range of emotions sufficiently to accept everything which happens there with that necessary calm which life in war demands unconditionally.' 67

Second, given the repetition and mechanical regularity of war, combined with desensitization to death and fear of death, some soldiers appear to have succumbed to automation and a lack of thought or feeling. Jünger, as a young officer wounded fourteen times (but returning to the front), revealed at once how it was possible to be numbed by war and to re-romanticise it, depicting troops as killing machines, replete with helmet, grenades, guns, and so on. There was 'poetry' in war - heroism and courage in adversity averred one German soldier in October 1914, but it co-existed with the 'unburied dead and helplessly wounded', in which 'fate manifests itself in its ugliest form'. ${ }^{68}$ Zschuppe's solution to controlling his nerves was to 'keep perfectly calm in body and mind': 'instead of sympathizing with the sufferings of others, I have become as one of them - looking on death with indifference because I myself may die at any moment, and no longer sickening at the sight of wounds and of dark-red blood on pale yellowish skin'.69 A large number of combatants on both sides noted a hardening of their sensibilities and a growing indifference to the suffering of others. 'Here's an instance' of 'the hardening of experience', wrote Ernest Boughton on 27 March 1916: 'I've just come from where fifty thousand bodies lie, bones and barbed wire everywhere, skeletons bleached if one takes a walk over the frightfully contested and blown up hill. - Boots and bones protruding from one's dug-out walls, and yet - one is merry there.'70 Running commentaries on soldiers' own mental collapse and emotional brutality - more often than merriness - were much more common in the First World War than they had been in earlier conflicts. ${ }^{71}$

Third, many contemporaries took refuge in myths and fantasies, which included the common feeling that men at the front had experienced death (as a presentiment, loss or spectacle), marking them out from other humans and binding them together in a 'community of the trenches'. 'An awakened fantasy,' stimulated by every gunshot and artillery shell, 'allows one no rest', wrote Adolf Brochhaus in July 1918.72 Confrontation with death, passing from exhilaration or apprehension to fear or indifference, constituted the core of most soldiers' accounts. Writing to his brother on 27 July 1917, Lieutenant Henry Paul Mainwaring Jones was typical in betraying a gamut of emotions:

Have you ever reflected on the fact that, despite the horrors of the war, it is at least a big thing? I mean to say that in it one is brought face to face with realities. The follies, selfishness, luxury and general pettiness of the vile commercial sort of existence led by nine-tenths of the people of the world in peacetime are replaced in war by a savagery that is at least more honest and outspoken. Look at it this way: in peacetime one just lives one's own little life, engaged in trivialities, worrying 
about one's own comfort, about money matters, and all that sort of thing - just living for one's own self. What a sordid life it is! In war, on the other hand, even if you do get killed you only anticipate the inevitable by a few years in any case, and you have the satisfaction of knowing that you have 'pegged out' in the attempt to help your country. You have, in fact, realized an ideal, which, as far as I can see, you very rarely do in ordinary life.... I think that the War has given to everyone a chance to 'get out of himself', as I might say. Of course, the other side of the picture is bound to occur to the imagination. But there! I have never been one to take the more melancholy point of view when there's a silver lining in the cloud.

Certainly, speaking for myself, I can say that I have never in all my life experienced such a wild exhilaration as on the commencement of a big stunt ....73

The majority of soldiers seem, after experiencing combat, to have concentrated on 'the other side of the picture'. Like Ernst Hieber in April 1915, they had seen 'many men killed' and this 'soon makes one feel rather lonely', left with the feeling that 'the dead were reproaching me': 'Why should I have been killed and not you?'74 Some, like Philip Russell Keightley (a student at Trinity College, Dublin), shut their eyes and ran, keeping their 'imagination well in hand and thinking about nothing but the shortest and safest way back', yet left with 'perspiration streaming off me, a very empty feeling in my stomach and a very weak feeling in my knees'. 75 Others seem to have come to feel relatively untouched by the injury and death of others.

Fourth, most combatants appear to have sensed, at various points, that the horrors of the First World War had undermined the fixity of their lives and the stability of the social and political order. War was described as a 'hell', 'fury', and 'bedlam'. ${ }^{76}$ It was 'a terrifying, raging horror', in the words of one Oberjäger writing from Liège at the start of the campaign. 77 Even before battle, soldiers had been 'oppressed by the first mental picture of horrors which are no longer mere possibilities, but actually approaching realities', as one German infantryman expressed it before taking the train to Chalons in September 1914.78 Once at the front, existence became 'that world of horror!'79 'In what bitter disappointment I now sit here, with horror in my heart!' wrote Alfred Buchalski from Belgium on 28 October 1914: 'It was ghastly! Not the actual shedding of blood, nor that it was shed in vain, nor the fact that in the darkness our own comrades were firing at us - no, but the whole way in which a battle is fought is so revolting. To want to fight and not even to be able to defend oneself!'8o As the conflict became a war of attrition, combatants passed from doubts and shock, through despair, to numbness and cynicism. Friedrich Georg Steinbrecher, a theology student from Leipzig, gave a typical, unflinching account of the fighting in France:

13 March 1916, before Pontavert

Went through the captured position. A swampy stretch of forest, consisting of shell-smashed trees and battered trenches, surrounds the hill. The whole place looks as if it had been ploughed up. Blown in dug-outs. Huge shell-craters. Fragments of wood and clothing; corpses; rifles; knapsacks. A field of wood and horror.

14 March

Had a stiff job: getting ammunition and material into the line. Gas-shells polluted the air. Men got buried. Attempts at artificial respiration. A fearful squash in the dug-outs. Only half can lie down 
at night, the rest have to sit or stand. I managed to do without going to the latrine for four days. Then it had to be risked. The strain on the nerves is terrible. Many break down altogether. I haven't been able to eat or sleep, from exhaustion. Yet I am forced to admire the way in which many a delicate chap keeps up. Germans have a damned lot of backbone. A man can always stand a bit more than he thinks he can. The time passes quickly. At night I am woken up suddenly by shells which keep me lively.

15 March

Every movement must be executed at the double. Every trip to fetch rations is an act of heroism, a matter of life and death. We badly need to be relieved. I am quite fit again. On the $14^{\text {th }}$ there was a partial attack. Successful.

17 March

Relieved tonight. At last. We had cleaned up the battlefield fairly well. Sights which I shall never forget. Sickening - sickening is the only word. But it has to be. ${ }^{81}$

By 12 April, Steinbrecher was embroiled in the battle of the Somme: 'The whole history of the world cannot contain a more ghastly word!'82 His feelings seem to have oscillated between glimmers of meaning - 'Those are the holiest moments in life which reduce one to silence' - and futility:

3 November 1916

The poetry of the trenches is a thing of the past. The spirit of adventure is dead. ... When one has seen how degrading war can be, any idyllic interval comes like a reprieve from the gallows. ... I sometimes feel so wintry inside. The war which began as a fresh youth is ending as a made-up, boring, antiquated actor. Death is the only conqueror. We are disillusioned, at least as regards what is called world-philosophy. 83

According to Ernest Boughton, writing in August 1915, soldiers' abiding recollections were 'stern' - 'of murderous bombardments, of pitiful mutilated bodies, of agonized cries by day and night'. ${ }^{84}$ Soldiers were in a wasteland, which they struggled to escape. To Philip Russell Keightley, now a captain, writing from France on 28 November 1917, 'I have seen all I ever want to see again.' ${ }^{5}$ 'I do not care to dwell on it, and I cannot describe my experience,' he continued: 'That would need the brutal realism of Zola.' 86 He then proceeded to describe in detail what happened. Many other soldiers logged their experiences, not with the realism of Zola, but in fragmented streams of consciousness. ${ }^{87}$

Millions of combatants wrote home, revealing the atrociousness of war in explicit terms. Many soldiers had already written in a similar fashion during the Wars of Unification but their letters were much more numerous, overt and, as a result, difficult to ignore during the First World War. ${ }^{88}$ As in earlier conflicts, greater licence was given to the written word than to images (in newspapers, periodicals, newsreels and films) or the spoken, enacted word (in plays). People were no longer 'spectators, simply interested in the deeds of the army', as in 1870, wrote Franz Carl Endres in Die Tragödie Deutschlands, they were 'themselves participating': 'In some form, all men and, even, most women were warriors' ${ }^{89}$ However, the effects of such involvement were uncertain, discussed at the time by psychologists and journalists. 'The feeling of security, of being protected, with which 
we experience those dangers of war in our fantasies amidst the tranquility of the home', allowed everyone to experience such conditions as if at play, recorded one commentator in 1915: this 'make-believe living through danger from a secure home', which occurred 'unconsciously', had 'a great role - greater than many readers of these sentences could comprehend' - on adults and children alike. $9{ }^{\circ}$ Yet the extent of such passive participation was contested at the time and is still disputed by historians. In this context, writers proved important as intermediaries.

\section{Literary Wars and Public Opinion in the United Kingdom}

There is considerable evidence that combatants' direct experiences of war were different in kind from impressions of fighting gained by citizens on the 'home front'. ${ }^{91}$ Soldiers regularly seem to have believed that they had been separated from civilian life, at once abandoned by civilians who knew nothing of front-line conditions, manipulated by politicians and their generals safe behind the lines, and betrayed by profiteers and working-class strikers and their socialist unions and parties at home. $9^{2}$ With such a degree of disaffection and loss of trust in civilians (or civilian authorities), having come close to death and having broken the interdiction against killing (without an obvious purpose, once the causes and aims of the war were questioned), such men were often difficult to reintegrate into peacetime societies, particularly in those states like Austria-Hungary and Germany which had collapsed as a result of defeat.93 They had continued to fight out of fear of military sanctions (with 3,00o death sentences and 346 actual executions in Britain, for example), from a feeling of patriotism combined with deep-seated habits of deference and obedience to their superiors in the class societies of pre-war Europe and, paradoxically, as the consequence of their unwillingness to give up their fellow soldiers for 'civilian life' or to admit that the suffering and killing had all been for nothing. ${ }^{44}$ These sentiments proved sufficient to sustain a degree of slaughter that was far worse than any experienced prior to that point. 95 Away from the front, however, and once the war had ended, such support and conformity were far less certain. It was in these circumstances that the main disputes about what the war meant took place. ${ }^{96}$

Writers played a pivotal part in such disputes, not merely because they were allowed greater licence to describe events, but also because they were able to collate, merge and interpret the individual testimonies of soldiers, making sense - or admitting their inability to make sense - of the war as a whole. ${ }^{97}$ Their interpretations were popular, with Robert Graves's Goodbye to All That (1929) selling 40,00o copies between 1929 and 1931 and Siegfried Sassoon's Memoirs of an Infantry Officer (1930) selling 48,00o in its first five years of publication. If wars were 'very local, limited, incoherent' to soldiers themselves, in Edmund Blunden's words, they could be understood by poets and novelists, not from above in the manner of historians (or generals), but from within..$^{8}$ There was a broad desire, reflects the narrator of H. G. Wells's Mr Britling Sees It Through, 'to see the war, to simplify it and extract the essence of it'. ${ }^{99}$ It was, especially, through literary reconstructions that soldiers' experiences and impressions came to dominate memories of the war, as writers' explorations of the horrors of trench warfare were consumed - at the 
same time - by a mass readership. ${ }^{100}$ Whereas cinema and theatre were censored during the war and subject to self-censorship after it, literature was 'private', even if its revelations and judgements became public (through the press and by word of mouth). Thus, the 'documentary' film The Battle of the Somme (1916), which was funded by the government and watched by about 20 million viewers in Britain, showed only one (faked) death, as the soldiers went over the parapet in the British army's bloodiest battle. ${ }^{101}$ Likewise, George Bernard Shaw's Heartbreak House, published in 1919 and first performed in London in 1920, exposed the fatuousness and snobbery of Edwardian society, whose rich characters welcomed bombs exploding in their garden as a means of relieving the boredom, but it never mentioned the war explicitly, despite laying bare the effects of the conflict. ${ }^{102}$ War novels and memoirs could be more brutal, though here, too, there were limits. The liberal publisher Samuel Fischer, which had Gerhart Hauptmann and Thomas Mann on its books, had refused to take Erich Maria Remarque's Im Westen nichts Neues (All Quiet on the Western Front). Ullstein had later agreed because it considered the German public - or sections of it - to be 'ready' in 1929. The work also appeared in the Vossische Zeitung, owned by the same publisher. The novel went on to sell two million copies - at home and abroad - in its first year, making it the most popular book in German publishing history to date. ${ }^{103}$

Remembrance of the war in both defeated and victorious states went through two separate stages. First, there was an extended period of mourning and an incomplete, often contradictory, silence, examined by Jay Winter in his book on Sites of Memory, Sites of Mourning, and embodied in the monumental architecture of Sir Edward Lutyens. ${ }^{104}$ This period of silent mourning and shock, which ran alongside the continuing publication of memoirs and different kinds of novels (patriotic, allusive, historical), lasted - with variations and exceptions - until the late $1920{ }^{105}$ It was followed by a second period of expurgation and catharsis; a period when soldiers and others published a rash of critical and controversial war memoirs and novels, and made many of the war - or anti-war films. ${ }^{106}$ Before then, as the writer Osbert Sitwell remarked, it had been very bad form in the United Kingdom to mention the war. This changed in the late 1920s, when a series of works appeared in quick succession (see table below).

Table: Well-known literary works about the First World War in the United Kingdom, 192633

1926 Ford Madox Ford, A Man Could Stand Up

T. E. Lawrence, Seven Pillars of Wisdom

Herbert Read, In Retreat

1927 T. E. Lawrence, Revolt in the Desert

Max Plowman, A Subaltern on the Somme

1928 Ford, Last Post

Edmund Blunden, Undertones of War

Siegfried Sassoon, Memoirs of a Fox-Hunting Man

E. E. Cummings, The Enormous Room

1929 R. C. Sherriff, Journey's End (play) 
Richard Aldington, Death of a Hero

Robert Graves, Goodbye to All That

1930 Henry Williamson, Patriot's Progress

Sassoon, Memoirs of an Infantry Officer

Frederic Manning, Her Privates We

1931 The Poems of Wilfred Owen (new edn.)

1933 Vera Brittain, Testament of Youth

Herbert Read, The End of a War

These works touch on a number of themes; the end of the myth of progress and the death of 'civilisation' (about which there were many works after 1918), the division between the front and home front, the conflict between generations and sexes, as well as the nature of the relationship between artifice (so obvious in the shell-torn no-man's land) and nature (so visible every morning at stand-to as the sun rose). In the treatment of all such themes in war memoirs such as that of Graves and semi-autobiographical war novels such as those of Sassoon - in common with works in the German language such as Karl Kraus's play Die letzten Tage der Menschheit (1918) - was a mixture of satire, ridicule, detachment and brutality, referring to horrors remembered but still not explained. ${ }^{107}$ This is what Paul Fussell means when he says that war literature - and perhaps Modernist literature in general after 1918 - was characterised by the ironic mode. ${ }^{108}$ In Sassoon's Memoirs of a Fox-Hunting Man (1928) and Memoirs of an Infantry Officer (1930), the ridiculousness of the war is created by juxtaposing an exaggeratedly naïve young country gentleman, whose only interests are to ride horses, chase foxes and shoot birds, with the deathly, brutalizing setting of industrial warfare. ${ }^{109}$ Like Gulliver, who visited worlds of different beings, George Sherston achieves a certain kind of wisdom as he is buffeted by forces in the war which he does not understand. The character is ridiculed by Sassoon as he writes to Mr Markington (H. W. Massingham) of the Unconservative Weekly (The Nation) in the tone of a comedic schoolmaster: 'I'm fed up with all the hanky-panky in the daily papers. '110 Yet the author's satire of Massingham and other anti-war intellectuals is equally cutting and bathetic: "'The soldiers are not allowed to express their point of view. In war-time the word patriotism means suppression of truth," he remarked, 'eyeing a small chunk of Stilton cheese on his plate as if it were incapable of agreeing with any but ultra-Conservative opinions.' 111 The reader sees Sherston begin the war as a robust, ruddycheeked supporter, willing to risk his own life in the defence of Britain's class-ridden, civilised country life ('Captain Huxtable was ... an epitome of all that was most pleasant and homely in the countrified life for which I was proposing to risk my own'), but he ends the war as one of the first military objectors. ${ }^{112}$

Sherston is alienated by the conditions and meaninglessness of the fighting front, even though he became a daredevil hero there, but he is unable to return to the caricatures of the home front. He resists the momentum of the 'war machine', with all its imbecilic imperatives, yet he cannot escape it, or think of a better alternative. Behind the lines in France, 
I leant on a wooden bridge, gazing down into the dark green glooms of the weedy little river, but my thoughts were powerless against unhappiness so huge. I couldn't alter European history, or order the artillery to stop firing. I could stare at the War as I stared at the sultry sky, longing for life and freedom and vaguely altruistic about my fellow-victims. But a second-lieutenant could attempt nothing - except to satisfy his superior officers; and altogether, I concluded, Armageddon was too immense for my solitary understanding. ${ }^{113}$

He gets to know 'the men' from other classes for the first time in his life and he reveals his admiration for them, but he also signals his disgust at their - and by association, his own - brutality and crudeness in their 'unlovely struggle' for survival. As he entered the 'demolished village' of St Martin-Cojeul,

I noticed an English soldier lying by the road with a horribly smashed head; soon such sights would be too frequent to attract attention, but this first one was perceptibly unpleasant. At the risk of being thought squeamish or even unsoldierly, I still maintain that an ordinary human being has a right to be momentarily horrified by a mangled body seen on an afternoon walk, although people with sound common sense can always refute me by saying that life is full of gruesome sights and violent catastrophes. But I am no believer in wild denunciations of the War; I am merely describing my own experiences of it; and in 1917 I was only beginning to learn that life, for the majority of the population, is an unlovely struggle against unfair odds, culminating in a cheap funeral. Anyhow, the man with his head bashed in had achieved theoretical glory by dying for his country in the Battle of Arras, and we who marched past him had an excellent chance of following his example. ${ }^{114}$

The topsy-turvy world of a 'patriotic' war - and the social injustices of the countries waging it - were laid bare by the cheerful commentary and unrelenting gaze of the first-person narrator. We see the transformation of Sherston's war - and his world - from a child's romance, full of playfulness and misunderstanding, to a horrifying and cynical nihilism.

Sassoon, Graves and Blunden were stuck in no-man's land: they stood outside and beyond civilian life, realising the futility and ridiculousness of it. They were either internal exiles like Sassoon - who spent the rest of his life writing about the war or the run-up to war - or actual exiles like Graves, who spent the rest of his life on the island of Majorca. ${ }^{115}$ Graves, who is the protagonist of his own war memoir, is much more cynical than Sassoon's alter ego George Sherston, volunteering for military service in a casual and worldly-wise attempt to avoid going up to Oxford and teaching thousands of troops at the Harfleur training centre 'How to be Happy, though in the Trenches'. ${ }^{116}$ His cynicism is on display in his re-telling of soldiers' tales, which seem indifferent to dismemberment and death, treated in direct speech as a popular joke, combined with Schadenfreude and, possibly, loyalty to the group:

Another story: 'Bloke in the Camerons wanted a cushy, bad. Fed up and far from home, he was. He puts his hand over the top and gets his trigger finger taken off, and two more beside. That done the trick. He comes laughing through our lines by the old boutillery. "See, lads," he says, "I'm off to bonny Scotland. Is it na a beauty?" But on the way down the trench to the dressing-station, he forgets to stoop low where the old sniper's working. He gets it through the head, too. Finee. We laugh fit to die!' 
To get a cushy one is all the old hands think of. Only twelve men have been with the battalion from the beginning, and all are transport men except one ....117

The atmosphere and meanings of Graves's prose are very close to those of his contemporaries. The war has brought men close to death and given them a special knowledge of existence, which marks them off from all others, but their existence has, at the same time, been rendered purposeless and absurd by the scale, wastefulness and horror of the slaughter. Graves, too, is a victim, looking at himself from the outside, without irony:

Should we ever live to hear [a shell] burst safely behind us? I wondered whether I could endure to the end with faith unto salvation ... My breaking-point was near now, unless something happened to stave it off. Not that I felt frightened. I had never yet lost my head and turned tail through fright, and knew that I never would. Nor would the breakdown come as insanity; I did not have it in me. It would be a general nervous collapse, with tears and twitchings and dirtied trousers; I had seen cases like that. ${ }^{118}$

What was it all for? This is a question that Graves and Sassoon are unable to answer: they certainly find no clue in the old shibboleths of loyalty to nation, international justice, fellow feeling, or even love for people at home - hence, Graves drifts in and out of a relationship after the end of the war, apparently feeling little for his wife or literary friends. ${ }^{119}$

\section{War Books and Political Division in Germany}

There is a sense in which Graves's and Sassoon's revulsion against war was less controversial in Britain than was Remarque's in Germany, for the war in both the United Kingdom and France, precisely because it had been victorious, could be seen by most - at home and returning from the front - to have been the war, as the phrase went, 'to end all wars'. ${ }^{120}$ Since the post-war status quo was broadly acceptable and the supposed aggressor had been defeated, the sacrifices and blood-letting could be seen to be worthwhile, and soldiers could be thanked and reintegrated, against the background of pacifism or, at least, opposition to aspects of war planning and modern warfare. ${ }^{121}$ The full sense of this horror of war is visible in Jean-Paul Sartre's Le Sursis (The Reprieve), but also in Chamberlain's and Daladier's policy of appeasement, which constitutes the setting of Sartre's novel.

All Quiet on the Western Front was published in Britain, complete with words such as 'shit', 'turd' and 'masturbate', without difficulty. ${ }^{122}$ In Germany (and other defeated states), by contrast, uninhibited, ironic or cynical pacifism (or non-pacific criticism of military conflicts), combined with an exposure of the full gothic horror of modern war, was much more contentious. ${ }^{123}$ Here, because of the defeat, soldiers were not universally and unproblematically honoured on a national stage, supported by virtually all political parties. The war remained divisive, fuelling the opposition of the nationalist right and

leaving much of the centre in a quandary. ${ }^{124}$ As a consequence, many of the unrealistic 
aspirations and inexplicable enmities of the home front remained prominent in public life. At the same time, the soldiers themselves - or many of them - felt let down and uncertain whether to accept defeat: had it really all been for nothing? Thus, when Erich Maria Remarque suggested in Im Westen nichts Neues that it all had been for nothing, many Germans - particularly but not only those on the right - violently refuted his claims. ${ }^{125}$

The principal themes of Im Westen nichts Neues were similar, in graphic form, to those of Graves and Sassoon: disenchantment (with 'the poorest and simplest people ... the most sensible', seeing 'the war as a disaster right from the start'); resentment against those on the home front ('while they went on writing and making speeches, we saw field hospitals and men dying'); unwillingness to demonize enemies (after hand-to-hand combat, 'It is only now that I can see that you are a human being like me'); anxiety about the randomness of death ('I can be squashed flat in a bomb-proof dugout, and I can survive ten hours in the open under heavy barrage without a scratch'); and powerlessness against the mechanization of warfare ('tanks are machines, ... a fleet of roaring, fire-spitting ironclads, invulnerable steel beasts that crush the dead and wounded'). ${ }^{126}$ Above all, war for Remarque was horrific:

We see men go on living with the top of their skulls missing; we see soldiers go on running when both their feet have been shot away - they stumble on their splintering stumps to the next shell hole. One lance-corporal crawls for a full half-mile on his hands, dragging his legs behind him, with both knees shattered. Another man makes it to a dressing station with his guts spilling out over his hands as he holds them in. We see soldiers with their mouths missing; we find someone who has gripped the main artery in his arm between his teeth for two hours so that he doesn't bleed to death. The sun goes down, night falls, the shells whistle, life comes to an end. ${ }^{127}$

This type of description was characteristic of letters and literary accounts of war in Germany and Britain, extending back to the Crimean War and Wars of Unification. ${ }^{128}$ It provoked such vociferous opposition in interwar Germany, not because of its explicit character, but because of its uncompromising criticism of the war, with Remarque linking his descriptions to a verdict:

'So why is there a war at all?' asks Tjaden.

Kat shrugs. 'There must be some people who find the war worthwhile.'

'Well, I'm not one of them,' grins Tjaden.

'No, and nor is anybody else here.' ....

Dead men are hanging in the trees. In one of them a naked soldier is squatting in the branches; his helmet is still on his head, but otherwise he has nothing on. There is only the top half of him up there, a head and body with the legs missing.

'What happened there?' I ask.

'Blown out of his uniform,' grunts Tjaden. ....

The dead man is lying on his face. The earth is black from the blood underneath the arm sockets. The ground is scuffed by his feet, as though he went on kicking for a while.

'It's no joke, Kat,' I say.

'Nor is a bit of shrapnel in the guts,' he says with a shrug.

'The main thing is not to let it all get to you,' adds Tjaden. ${ }^{129}$ 
Such experiences, though, did get to German soldiers. When Kat, the cynical working-class friend of the protagonist, is killed, Paul remembers 'nothing'. ${ }^{130}$ As the war nears its end, he is sure that 'No one will understand us'. ${ }^{131}$ 'Let the months come, and the years, they'll take nothing more from me, they can take nothing more from me', he concludes: 'Life, which carried me through these years, is still there in my hands and in my eyes .... Whether or not I have mastered it, I do not know. But as long as life is there it will make its own way, whether my conscious self likes it or not.' ${ }^{132}$ These were feelings described by many combatants which Remarque's account - presented by Ullstein as a true depiction by an ordinary soldier - disseminated to a mass readership. ${ }^{133}$ A large majority of critics thought that Im Westen nichts Neues was a timely, non-literary 'document', with over a third of them stating that it had no 'tendency' at all.134 In their opinion, Remarque was putting words to millions of private letters and documentary fragments already known to the public. To opponents, such as the Nazi critic Hans Zöberlein in the Völkische Beobachter in 1929, Remarque had created a 'memorial of excrements' which besmirched the frontline soldier. ${ }^{135}$

Remarque's most prominent opponent - amongst war novelists - was Ernst Jünger, who had joined the German army, like Graves, from school and had gone on to be injured many times, returning to the front on each occasion. Like most soldiers, Jünger had long ago lost his romantic vision of warfare. His first and most famous war book, In Stahlgewittern (Storm of Steel), which was published in 1920, shows the horror of conflict in similar terms to the work of Remarque, deploring the monotony and discomfort of the trenches, the randomness of the various assaults, the mistakes and foolishness of the General Staff, and the treachery of the home front. ${ }^{136}$ However, Jünger was driven to reidealise military conflict, portraying soldiers as machines of war, facing the likelihood of death with an iron-like will and testing their nerves against modern matériel:

the strangest thing of all was not the horror of the landscape in itself, but the fact that these scenes, such as the world had never known before, were fashioned by men who intended them to be a decisive end to the war. Thus all the frightfulness that the mind of man could devise was brought into the field; and there, where lately there had been the idyllic picture of rural peace, there was as faithful a picture of the soul of scientific war. In earlier wars, certainly, towns and villages had been burned, but what was that compared with this sea of craters dug out by machines? For even in this fantastic desert there was the sameness of the machine-made article. A shell-hole strewn with bullytins, broken weapons, fragments of uniform, and dud shells, with one or two dead bodies on its edge ... this was the never-changing scene that surrounded each one of all these hundreds of thousands of men. And it seemed that man, in this landscape he had himself created, became different, more mysterious and hardy and callous than in any previous battle. The spirit and tempo of the fighting altered, and after the battle of the Somme the war had its own peculiar impress that distinguished it from all other wars. After this battle the German soldier wore the steel helmet, and in his features there were chiseled the lines of an energy stretched to the utmost pitch, lines that future generations will perhaps find as fascinating and imposing as those of man heads of classical or Renaissance times. ${ }^{137}$ 
Jünger comes to revel - in the novel more than in his war diary - in the butchery of war (as if he is in the lawless Wild West) and the potential for destruction which modern weapons give individual soldiers. ${ }^{138}$

Men were supposedly bound together in a new way by their very powerlessness against artillery and machine guns, and the vastness and anonymity of military organization: this was a new type of community of the trenches which could be transferred to civilian life or, at least, which made civilian life, as it existed, look craven and weak. As Jünger looked back on 'four years of development in the midst of a generation predestined to death, spent in caves, smoke-filled trenches, and shell-illumined wastes', he saw that 'the idea of the fatherland had been distilled from all these afflictions in a clearer and brighter essence'. ${ }^{139}$ Having been schooled 'to stake my life for its credit every minute, day and night, without a thought', the young soldier had come to realize that 'the nation was no longer for me an empty thought veiled in symbols'. ${ }^{140}$ Men in the trenches had been shown the futility of thought and reflection, and the power of action: they had undergone the hardening and brutalization necessary for life in industrial societies. Jünger went on:

And so, strange as it may sound, I learned from this very four years' schooling in force and in all the fantastic extravagance of material warfare that life has no depth of meaning except when it is pledged for an ideal, and that there are ideals in comparison with which the life of an individual and even of a people has no weight. And though the aim for which I fought as an individual, as an atom in the whole body of the army, was not to be achieved, though material force cast us, apparently, to the earth, yet we learned once and for all to stand for a cause and if necessary to fall as befitted men.

Hardened as scarcely another generation ever was in fire and flame, we could go into life as though from the anvil; into friendship, love, politics, professions, into all that destiny had in store. It is not every generation that is so favoured.

And if it be objected that we belong to a time of crude force our answer is: we stood with our feet in mud and blood, yet our faces were turned to things of exalted worth. And not one of that countless number who fell in our attacks fell for nothing. ${ }^{141}$

Jünger's description of war is similar to that of Remarque, Graves and Sassoon, but his evaluation of it has been reversed. He sees civil society as worthless and empty and wants to revitalize it through the activity, adrenalin, ruthlessness and feeling of life confronted by death which he had found in the trenches. ${ }^{142}$ This revitalization in turn seemed to offer the possibility of defeating old enemies, pursuing a policy of expansion, and regaining national honour. In a defeated power such as Germany, these radical views became popular during the 1920 s and early 1930 s. They emerged from a patriotic, even sacred, realm of war literature, in which the horrors of military conflict had been described and justified without inhibition or censorship.

\section{Writing about War}

A comparison of the content and reception of 'war literature' in the United Kingdom and Germany reveals striking similarities in the diction, imagery and form of letters, diaries, 
memoirs and novels. ${ }^{143}$ Written accounts of the war drew on existing traditions and vocabularies which allowed authors to describe events and explore feelings during the war as well as after it in ways that were usually forbidden for painters, cinematographers, and playwrights. ${ }^{144}$ For proponents of high culture, such as Thomas Hardy, the shift marked a decline of poetry and the barbarizing of taste in the younger minds by the dark madness of the late war'. ${ }^{145}$ To D. H. Lawrence, it was symptomatic of the fact that people 'have felt much more deeply and strongly these last few months', leading to the discrediting of "serious" works whose feeling is shallower than that of the official army reports'.146 Writers like Lawrence self-consciously called upon private expressions - which were occasionally published - of fear, jubilation, numbness and despair on the part of combatants during the conflict itself.

The boundaries between the varying types of war literature were not clear-cut. During the conflict, letters were printed routinely in the press. Newspaper and magazine articles regularly contained the testimony of eye witnesses, from which they derived much of their veracity and authority. ${ }^{147}$ In both Britain and Germany, hundreds of memoirs, diaries, collections of letters and other non-fiction 'war books' were published in the decades after 1918.148 Many memoirs were written by officers and ordinary soldiers, with some relying heavily on diaries and others on an individual's power of recollection. 'Literary' accounts variously imitated and extended the war memoir as a form of authentic testimony, rendering them 'generically mixed'. ${ }^{149}$ Jünger's In Stahlgewittern (1920) uses the form of a diary. Edmund Blunden's Undertones of War (1928) is a memoir but it includes the testimony of others in order to describe what war was like elsewhere. ${ }^{150}$ Ludwig Renn's Krieg (1928) is presented as an autobiographical memoir, yet its protagonist is an ordinary soldier, whereas Renn himself was an officer. Graves's memoir Goodbye to All That (1929) frequently shifts to a third-person narrator or relates 'typical' anecdotes through an empty first-person narrator ('I'). The experiencing self, which establishes - or seeks to establish - the authenticity of the account, is deliberately intermixed with the narrating self, which interprets events. ${ }^{15^{1}}$ Sassoon's Memoirs of an Infantry Officer (1930) created the fictional character of George Sherston in the manner of a novel, before going on to detail the events which had actually befallen the author. At the same time, the novel was a satire, alternating between graphic description and comic exaggeration. ${ }^{152}$ Many works combined caricatural or grotesque visions with 'factual' reportage or historical narrative. Karl Kraus's sprawling satirical drama Die letzten Tagen der Menschheit, composed and published between 1915 and 1922, had deployed these combinations to devastating effect.153 Both Richard Aldington's Death of a Hero (1929) and Remarque's Im Westen nichts Neues (1929) drew on traditions of caricature and the grotesque. For the former, who had read the latter in translation and believed 'that it's a great book and a great thing to have done', these grotesque elements were real: the war had been 'so brutal that its brutality cannot be exaggerated', Aldington wrote of All Quiet on the Western Front. 154

The 'authenticity' of such accounts, which seemed to connect them to the outpourings of soldiers during the war, rested on their reconstruction of particular types of events and combatants' reactions to them more than on meticulous or 'accurate' observation and forensic investigation of causal linkages. For Aldington, 'the work of art demands a sort of restraint, and the choosing of typical rather than exceptional horrors'. ${ }^{155}$ Aldington had 
enlisted in 1916, serving for almost three years, with extended periods of fighting. It was essential for him, as his commentary on All Quiet on the Western Front and on R. C. Sherriff's sell-out play Journey's End (1928) made plain, that he conveyed the unheroic materiality of military conflict: the death of the hero in the title was, amongst other things, the death of heroism. When the author was asked to remove obscenities - mainly swearing and allusions to sex (replacing 'fucking' with 'mucking') rather than references to violence - in order to make the text publishable (avoiding a trial like that of D. H. Lawrence in 1928), Aldington preferred to use asterisks, avowing in the preface that 'it is better for the book to appear mutilated than for me to say what I don't believe'. ${ }^{156}$ Edmund Blunden's review, which Aldington had feared, remarked that Death of the Hero contained 'some of the closest and strongest narration of Western Front warfare that has been produced', marked out by 'indignation and study of revenge', not 'coolness or detachment'. ${ }^{157}$ The 'truth' of the work derived, not from objectivity, but from its ability to make sense - or recreate the emotion - of soldiers' experiences. War had become a - perhaps the primary locus of existential revelation or 'ultimate experience, as Yuval Noah Harari has indicated, because of the transformation of the ways in which feelings were conceived of (tied to materialism, sensation and a Romantic 'sublime') and - I have argued here because of the changing technologies and conditions of modern life and military conflict. ${ }^{158}$

Writers - most of whom had been soldiers - extended the responses of combatants to modern warfare between 1914 and 1918. Their role was to make individual, private descriptions of the fighting 'public' or 'common' knowledge and to provide an overall judgement of the First World War's effects. Many letters and extracts from diaries had been published during the conflict itself, but they had continued to co-exist - as was frequently the case in the correspondence of each combatant - with tales of heroism and courage, together with a wider acceptance of the regrettable necessity of the war. Propaganda - some of which was produced by soldiers themselves - and efforts to maintain the morale of the troops (rotation between the fighting front and the rear, leave, entertainment, maintenance of ties with 'home') ensured the obedience of a large majority of combatants on both sides, with regular appeals to duty, self-sacrifice, bravery, religious belief, moral rectitude and, even, a necessary or just war. ${ }^{159}$ Such appeals persisted after the war in soldiers' memoirs and in literary works. ${ }^{160}$

Novels and autobiographies which challenged this version of events were subjected to extensive criticism. 'For sheer petulance and ill-temper I doubt if Death of a Hero can be matched,' wrote St John Ervine in the Daily Express: 'Mr Aldington must pardon his readers if they judge him to be a peevish person in sad need of being turned over one's knee and severely spanked.' ${ }^{161}$ Some combatants such as Geoffrey Dugdale strove to avoid 'as much as possible the gruesome and disgusting sides of the war', which he claimed whilst betraying their continuing presence - were 'dim in my memory and thankfully forgotten'. ${ }^{162}$ Charles Douie lamented in The Weary Road (1929) that 'the authors of this poetry and prose of horror and carnage have overstated the case in quite as great a degree as we understated it during the war'. ${ }^{163}$ However, he - like Dugdale - continued to concede that 'war gave us in full measure much that we would wish to forget in the way of sorrow and suffering', requiring authors to 'redress the balance of the old war literature'. ${ }^{164}$ By the 
late 1920 s and early 1930 s, such writers betrayed the extent to which 'horror and carnage' were associated with the war. Historians had not managed to convey this 'truth' of the war, averred the historian and memoirist Guy Chapman in his anthology of 'war literature' (or writing about the conflict). 'The nearest contacts with truth are the accounts of eyewitnesses of incidents from which a general picture can be built up,' he wrote in Vain Glory (1937): 'That is all this book tries to present, a general picture.'165

The success of Remarque's All Quiet on the Western Front was central to the establishment of disenchantment and horror as major themes in the literature of the First World War. The book sold 25,000 copies in Britain in the first month and 250,000 in its first year. ${ }^{166}$ Publishers rushed other similar works into print, with 12 non-fiction 'war books' appearing in the United Kingdom in 1929 and 35 in 1930. ${ }^{167}$ The critical reception of All Quiet was as mixed in Britain as it was in Germany, Janet Watson has contended. ${ }^{168}$ Yet a comparison of the controversy surrounding war books at the end of the 1920 reveals significant differences between the cultural discourses of combat. In both countries, the work continued to attract a mass readership. Twelve editions (out of a total of twenty known editions worldwide at that time) had already sold approximately 2.5 million copies by April $1930 .{ }^{169}$ Remarque was 'the author today with the largest audience in the world', recorded the Nouvelles Litter raires in October of the same year. ${ }^{170}$ In Germany, though, the publication of the book and the screening of Lewis Milestone's film of the book provoked vituperative protests on the right.

In December, at the first public showing of a special German version of All Quiet in Berlin, with the most controversial scenes already edited out, National Socialists, who had bought up about one-third of the seats (300 or so), stopped the performance, releasing stink bombs and starting fights. ${ }^{171}$ Socialists and left liberals defended the film's 'grandiose portrait of war' and 'this document of our four-year passion', attacking the nationalist right for its actions. ${ }^{172}$ The right and Centre Party called the film an insult, with Germania which was close to the Centre Party Chancellor Heinrich Brüning - declaring that the film was an insult to the memory of two million dead German soldiers and that its showing should not have been allowed. ${ }^{173}$ After further protests over the next few days, a conservative-minded film censorship board banned the film in Germany as a whole - after taking statements from various parties including the Ministry of Defence (which had recommended a ban before the film's release) and the Foreign Office (which had favoured its release, but had changed its mind) - on the grounds that it harmed the country's image. ${ }^{174}$ In Britain, France and the United States, the film had been showing to packed audiences since May 1930, going on to win awards for best picture and best director from the American Academy of Motion Picture Arts and Science in early 1931.

Criticism of Im Westen nichts Neues in Germany pre-dated the making of Milestone's film. Carl Zuckmayer's first review for the Berliner Illustrirte Zeitung labelled the work a 'war diary', in accordance with Ullstein's publicity campaign. ${ }^{175}$ Others, however, quickly came to question Remarque's war record, subsequently following the lead of Peter Kropp, who claimed that he had got to know the author in hospital in Duisburg - where the later author had stayed between 3 August 1917 and 31 October 1918 - and that his fellow patient had had a self-inflicted wound (Heimatschu $\beta$ ). ${ }^{176}$ Remarque had fought in Flanders in June-July 1917, being wounded - reported the army minister in December 1930 - in the 
left knee and under one arm on 31 July. 177 The author, it soon became evident, was not an unknown soldier but a journalist for Scherl's glossy magazine Sport im Bild. He had come up with the idea of writing a book about soldiers' experiences of war with little warning in 1928, having written an inconclusive review of works by Jünger, Franz Schauwecker and Georg von der Vring in June of the same year. ${ }^{178}$ Writing during the evening and at the weekend, he finished Im Westen nichts Neues in six weeks. These facts did not mean that Remarque was an opportunist, inspired by his own personal frustrations in the circumstances of the Great Depression, and they did little to undermine his own explanation, which had tied the disquiet of the late 1920s to that of the war: 'All of us were, and still are, restless, aimless, sometimes excited, sometimes indifferent, and essentially unhappy.' ${ }^{179}$ Yet the same facts were connected to the changing critical fortunes of the work, identified by Thomas Schneider, which passed from a first phase (November 1928 to January 1929) in which most critics lauded the true 'facts' and 'atmosphere' of the 'diary', via a second phase (February to July 1929) when reviews were more mixed and even liberal commentators started to label the account 'anti-war', to a third phase (August 1929 onwards) in which few reviews ascribed any degree of 'truth' to the text and many denied its veracity. ${ }^{180}$

A large number of Germans - especially the young, veterans and the supporters of the SPD and liberal parties - continued to read the novel, prefiguring the defence of Milestone's film of All Quiet on the Western Front by left-wing newspapers and sections of the liberal press in December 1930. What had happened, as the 'scandals' concerning the book and the film demonstrated, was that Remarque's perceived criticism of the German war effort had come into conflict with the positive mythology of the right - the intellectuals of the 'conservative revolution', the media empire of Alfred Hugenberg (who also owned UFA, which had refused to distribute or show Milestone's film), and the politicians and supporters of the Centre Party, the DVP, DNVP and NSDAP, all of whom had sought to discredit the work. As has been seen, Remarque's actual account of the war was similar in important respects to those of his British counterparts and to those of 'nationalist' German authors. His verdict on the war corresponded to those of the former but opposed those of the latter, with the result that All Quiet on the Western Front became a pivotal publication in a wider shift towards 'disenchantment' in Britain and a source of political division in Germany.

Recent historiography has tended to emphasize the persistence of 'patriotic' literature in Britain and the controversy which surrounded accounts of 'horror' and 'carnage'. It overlaps with a broad qualification by German historians of the notions of a 'lost generation', alienation, a community of the trenches, and a war-inspired brutalization or radicalization of politics (and art). Many such qualifications are justified, yet they do little to disprove the existence of close connections and substantive convergence between soldiers' testimony during the First World War and later literary accounts and judgements of the conflict in both Britain and Germany. The post-war cultures of the two societies were certainly different, helping to explain the varying reception of war books. It is difficult to deny, however, the perceived impact and actual significance, even primacy, of victory and defeat in the cultural meanings of - and debates about - war. Writing about war continued in both countries, with authors from across the political spectrum willing to 
break taboos in a fashion similar to that of soldiers during the conflict itself. Writing against war, by contrast, proved much more divisive in Germany than in the United Kingdom or elsewhere. 
${ }^{1}$ Kazin, Bright Book of Life, 84.

${ }^{2}$ Winter, Sites of Memory, Sites of Mourning, 9. See also idem, Remembering War.

3 Barbusse, quoted in J. M. Winter, Sites of Memory, 185. On Remarque, see Krimmer, The Representation of War, 6, 88-106; on Hemingway, see Norris, "The Novel as War", Modern Fiction Studies 40 (1994): 689-710. See also Bogacz, “'A Tyranny of Words”, Journal of Modern History 58 (1986): 643-68.

4 Natter, Literature at War.

5 For a recent interpretation, see McLoughlin, "War and Words", in idem (ed.), The Cambridge Companion to War Writing, 15-24.

${ }^{6}$ See Welke, "Gemeinsame Lektüre und frühe Formen von Gruppenbildungen", in Dann (ed.), Lesegesellschaften und bürgerliche Emanzipation, 71-99; idem, "Die Presse und ihre Leser", in K. Beyrer and M. Dallmeier (eds.), Als die Post noch Zeitung machte, 1407; Brophy, Popular Culture and the Public Sphere in the Rhineland. I have written about this in M. Hewitson, Absolute War, 76-86, and idem, The People's Wars, 181-254. 7 Lambert and Badsey (eds.), The War Correspondents: The Crimean War; F. Becker, “Der 'vorgeschobene Posten' als ‘verlorener Posten'?” in Maag, Pyta and Windisch (eds.), Der Krimkrieg als erster europäischer Medienkrieg, 221-34.

8 Belgum, Popularizing the Nation; Paul, Bilder des Krieges, Krieg der Bilder.

9 Kühlich, Die deutschen Soldaten im Krieg von 1870/71.

${ }^{10}$ Ulrich, Die Augenzeugen, 22.

${ }^{11}$ Hamilton and Herwig (eds.), The Origins of World War I, 4; Stevenson, Armaments and the Coming of War, 135 .

${ }_{12}$ Didczuneit, Ebert and Jander (eds.), Schreiben im Krieg - Schreiben vom Krieg; Ulrich, "Feldpostbriefe im Ersten Weltkrieg. Bedeutung und Zensur", in Knoch (ed.), Frontalltag, 40-83; Latzel, "Kriegsbriefe und Kriegserfahrung," Werkstatt Geschichte 22 (1999): 7-24.

13 Alan Kramer, Dynamic of Destruction, 329, himself is anxious to caution that the 'dynamic of destruction was not a law of nature; rather, despite the tremendous pressure of nature, technology, and mentalities, it was man-made, capable of infinite variation, and as we saw with the German decision to end the war, capable of being stopped before ultimate self-destruction'. On international relations and the collapse of the Concert of Europe, Hinsley, Power and the Pursuit of Peace, is still the classic account. Christopher Clark's Sleepwalkers, which is based on a much broader set of studies in German and English, seems to confirm the case - in the years before 1914 - about an unintended escalation in a multipolar world.

14 On the political contestation of 'memory', see Ziemann, Contested Commemorations. On memory and religion, see Winter, Sites of Memory, Sites of Mourning; idem, The Experience of World War I; idem, "Forms of Kinship and Remembrance in the Aftermath of the Great War," in idem and Sivan (eds.), War and Remembrance in the Twentieth Century, 40-60. On community and family, see Ziemann, Front und Heimat. 15 Watson, Enduring the Great War: Combat; Reimann, "Semantiken der Kriegserfahrung und historische Diskursanalyse. Britische Soldaten an der Westfront des Ersten Weltkrieges," in Buschmann and Carl (eds.), Die Erfahrung des Krieges, 17394; Mayer, The Persistence of the Old Regime; Eksteins, Rites of Spring: The Great War and the Birth of the Modern Age; G. L. Mosse, Fallen Soldiers: Reshaping the Memory of the World Wars; P. Fussell, The Great War and Modern Memory.

${ }_{16}$ Wohl, The Generation of 1914, 42-121; Williams, "The Myth of the Lost Generation," Clio 12 (1982): 45-56; Winter, The Great War and the British People, 65-102.

17 Leed, No Man's Land: Combat and Identity in World War I. 
${ }^{18}$ Fuller, Troop Morale and Popular Culture; Englander, "Soldiering and Identity: Reflections on the Great War," War in History 1 (1994): 300-318; McCartney, Citizen Soldiers.

${ }_{19}$ Ziemann, Front und Heimat.. From the other side, see Chickering, The Great War and Urban Life in Germany.

${ }^{20}$ Bourke, Dismembering the Male: Men's Bodies, Britain and the Great War; S. Levsen, "Constructing Elite Identities," Past and Present 198 (2008): 147-83.

${ }^{21}$ Cohen, The War Come Home; Bond, The Unquiet Western Front: Britain's Role in Literature and History; R. M. Bracco, Merchants of Hope: Middlebrow Writers of the First World War; Cecil, The Flower of Battle.

${ }^{22}$ See, for instance, Meyer, "The Tuition of Manhood: "Sapper's" War Stories and the Literature of War," in Hammond and Towheed (eds.), Publishing in the First World War, 113-28; Cullen, "The Land of My Dreams: The Gendered Utopian Dreams and Disenchantment of British Literary Ex-Combatants of the Great War," Cultural and Social History 8 (2011): 195-211. 'Genre' here is used in the broad sense of an accepted category of literature with at least some shared content or stylistic conventions, not in the narrower sense of certain literary critics: see, for instance, Devitt, Writing Genres. For a broader use of the term, similar to that alluded to here, see Hüppauf, "War literature," in Hirschfeld, Krumeich, and Renz (eds.): Brill's Encyclopedia of the First World War, 135-145, and idem, Was ist Krieg? Zur Grundlegung einer Kulturgeschichte des Kriegs. See also Beaupré, "New Writers, New Literary Genres (1914-1918)," in Purseigle (ed.), Warfare and Belligerence, 323-46.

23 Watson, Experience, Memory, and the First World War, 3.

24 On the significance of defeat, see especially Gerwarth, The Vanquished: Why the First World War Failed to End.

25 Givoni, "Witnesses in Public," in idem, The Care of the Witness, 99-135. This is not to contend that letters and diaries, much less memoirs, were indistinguishable from each other, but merely to point out that there were common images and styles of writing in all three types of testimony: see Fulbrook and Rublack (eds.), "In Relation: The 'Social Self' and Ego Documents," special issue of German History 28 (2010): 263-357.

${ }^{26}$ On the similarities, see especially Reimann, Der große Krieg der Sprachen.

27 In general, see Stromberg, Redemption by War.

${ }_{28}$ Mommsen, "German Artists, Writers and Intellectuals and the Meaning of War, 19141918," in Horne (ed.), State, Society and Mobilization, 21-38.

29 Roy, in Philipp Witkop (ed.), German Students' War Letters, 69. See Schicht, diary entry, 8 Sept. 1914, Häring (ed.), Ein Held der Garde, 16.

$3^{\circ}$ Richter, Dada: Art and Anti-Art, 25.

${ }^{31}$ Hynes, $A$ War Imagined, 1-96.

$3^{2}$ A. D. Gillespie to his parents, 1 Oct. 1914, in Laffin (ed.), Letters from the Front, 12.

33 On enemies within and atrocity stories in Britain, see de Groot, Blighty: British

Society in the Era of the Great War, 187-94.

34 Marquis, "Words as Weapons: Propaganda in Britain and Germany," Journal of Contemporary History 13 (1978): 467-98.

35 Stanley Baldwin, at the time the Joint Financial Secretary to the Treasury, speaking the House of Commons, in Messinger, British Propaganda and the State, 141.

${ }^{36}$ Stark, "All Quiet on the Home Front," in Coetzee and Shevin-Coetzee (eds.), Authority, Identity and the Social History of the Great War, 57-80; Welch, Germany: Propaganda and Total War.

37 Ponsonby, Falsehood in War-Time. For a detailed examination of the actual atrocities, see Horne and Kramer, German Atrocities, 1914.

${ }^{38}$ Schramm, Das Deutschlandbild in der britischen Presse 1912-1919, 413. 
39 De Groot, Blighty, 187-91.

40 There were, of course, atrocities but much of press reportage was false: see Wilson, "Lord Bryce's Investigation into Alleged German Atrocities," Journal of Contemporary History 14 (1979): 369-383. For a recent analysis of the wider debate, see Keller, Schuldfragen. Belgischer Untergrundkrieg und deutsche Vergeltung, 17-42.

${ }^{41}$ See especially Stibbe, German Anglophobia and the Great War.

${ }^{2}$ Sombart, Händler und Helden.

43 See, for instance, Marwick, The Deluge: British Society and the First World War, 1551.

44 The classic work is Fischer, Griff nach der Weltmacht.

45 On the debates about war and peace, see Mulligan, The Great War for Peace, 133-266. ${ }^{46}$ Leed, No Man's Land, 73-114.

47 J. Duncan to Rev. Duncan McArthur, 5 Sept. 1918, in Housman (ed.), War Letters of Fallen Englishmen, 96.

48 Ibid., 97.

49 On Germany, see Lipp, Meinungslenkung im Krieg; on Britain, B. Bond, The Unquiet Western Front; Isherwood, "The British Publishing Industry and Commercial Memories of the First World War," War in History 23 (2016): 323-40.

5o Ludwig to Kätchen Weber, 10 Sept. 1914, in Schöttler (ed.), 1914 in Briefen und Feldpostbriefen, 99.

${ }^{51}$ Hirschfeld, Krumeich and Renz (eds.), Enzyklopädie Erster Weltkrieg, 857.

$5^{2}$ See also Winter, "Victimes de la guerre. Morts, blesses et invalides," in Audoin-

Rouzeau and Becker (eds.), Encylopédie de la Grande Guerre 1914-1918, 1077.

53 For instance, Sparr (ed.), Feldpostbriefe 1914-1915, 276-7.

54 Wells, Mr Britling Sees It Through, 206.

55 Fussell, 184.

${ }^{5}$ Ibid.

57 Ibid.

$5^{8}$ Leed, No Man's Land: Combat and Identity in World War I, remains the seminal study of such expectations, though historians now accept that many combatants did not have such hopes.

59 Wolfram Wette, especially, has studied varying manifestations of such feelings: Wette (ed.), Der Krieg des kleinen Mannes.

6o Jünger, In Stahlgewittern, 107-10, showed that soldiers were usually subject to the overwhelming forces of a 'mechanical war' whilst also able to demonstrate their heroism during murderous and decisive interludes of hand-to-hand combat, for example. See especially Kiesel (ed.), Ernst Jünger. Kriegstagebuch 1914-1918, and idem, Ernst Jünger. Die Biographie.

${ }^{61}$ The literature on this subject is large. For German troops' responses and treatment, see Lerner, Hysterical Men: War, Psychiatry and the Politics of Trauma in Germany; Kaufmann, "Science as Cultural Practice," Journal of Contemporary History 34 (1999): 125-44; Eckart, Man, Medicine, and the State, and idem, Medizin und

Kolonialimperialismus. Deutschland 1884-1945; idem, "The Most Extensive Experiment that the Imagination Can Conceive," in Chickering and Förster (eds.), Great War, Total War, 133-49; idem, "'Eiskalt mit Würgen und Schlucken'. Körperliches und seelisches Trauma in der deutschen Kriegsliteratur, 1914-1939," Trauma und Gewalt 1 (2007): 186-199; idem, "Aesculap in the Trenches: Aspects of German Medicine in the First World War," in Hüppauf (ed.), War, Violence and the Modern Condition, 177-193; Eckart and Gradmann (eds.), Der Medizin und der Erste Weltkrieg; Ulrich, "Nerven und Krieg," in Loewenstein (ed.), Geschichte und Psychologie, 163-91. For further literature 
on British soldiers, see Loughran, Shell-Shock and Medical Culture in First World War Britain.

62 Häring (ed.), Ein Held der Garde, 39.

63 C. H. Sorley to A. Watts, 5 Oct. 1915, in Housman (ed.), War Letters of Fallen Englishmen, 252.

64 H. Zschuppe, 25 Oct. 1916, in Witkop (ed.), German Students' War Letters, 365.

65 W. Tharann (ed.), Aus dem Kriegstagebuch eines Gefallenen, 10.

66 W. Wimmel to M. Großbaum, 29 Nov. 1914, in M. Böhme (ed.), Kriegsbriefe der Familie Wimmel, 169.

${ }_{67}$ D. Vallendar to L. Wimmel, 18 Dec. 1914, ibid., 209.

68 T. to E. Römer, 27 Oct. 1914, in H. Schöttler (ed.), 1914 in Briefen und Feldpostbriefen, 120-1.

69 Ibid.

${ }^{70}$ E. Boughton to C. Williams, 27 Mar. 1916, in Housman (ed.), War Letters of Fallen Englishmen, 202.

${ }^{71}$ See Hewitson, “German Soldiers and the Horror of War," History 101 (2016): 396-424. ${ }^{2}$ A. Brochhaus, diary entry, 26 July 1918, in Schupp (ed.) Eines Freiburger Theologen Kreigstagebücher 1914/18, 97.

73 H. P. Mainwaring Jones, 27 July 1917, in Housman (ed.), War Letters of Fallen Englishmen, 159.

74 E. Hieber, 14 Apr. 1915, in Philipp Witkop (ed.), German Students' War Letters, 66. See also C. H. Sorley to A. Watts, 26 Aug. 1915, in Housman (ed.), War Letters of Fallen Englishmen, 250.

75 Laffin (ed.), Letters from the Front, 88.

${ }^{76}$ For instance, one lieutenant at the battle of the Marne in September 1914 referred to a 'Hexenkessel': Förster (ed.), Wir Kämpfer im Weltkrieg, 83.

77 Ibid., 3.

78 Witkop (ed.), German Students' War Letters, 2.

79 Ibid., 4.

80 A. Buchalski, 28 Oct. 1914, ibid., 13.

${ }^{81}$ F. G. Steinbrecher, 13-17 Mar. 1916, ibid., 320-1.

82 Ibid., 322.

83 Ibid., 324-5.

84 E. Boughton to F. J. Page, 20 Aug. 1915, in Housman (ed.), War Letters of Fallen Englishmen, 199.

85 P. R. Keightley, 28 Nov. 1917, in Laffin (ed.), Letters from the Front, 86.

86 Ibid.

87 I have written about this at greater length in "I Witnesses: Soldiers, Selfhood and Testimony in Modern Wars," German History 28 (2010): 310-25.

88 This does not mean that all soldiers wrote in such a fashion, of course. Many stuck to the formulae of the Field Service Postcard or attempted to spare the feelings of those at home. Fussell, 184.

89 F. C. Endres, Die Tragödie Deutschlands, 283

$9^{\circ}$ Dix, Psychologische Beobachtungen über die Eindrucke des Krieges, quoted by B.

Ulrich, Die Augenzeugen, 123.

${ }^{91}$ Benjamin Ziemann, War Experiences in Rural Germany, 82-98, 137-54, rightly

emphasizes persisting ties between soldiers, their families and localities, but he, too,

shows the divisions which existed between the fighting front, 'profiteers', political parties, the army hierarchy and the government. Also, Nelson, German Soldier Newspapers of the First World War. On Britain, see Nelson, "Soldier Newspapers," War in History 17 (2010): 167-91; Wilson, The Myriad Faces of War; Bourne, Britain and the 
Great War; Tooley, The Great War; Monger, "Soldiers, Propaganda and Ideas of Home and Community in First World War Britain", Cultural and Social History 8 (2011): 33154 .

92 Many historians contend that the gap between combatants and civilians, whether propped up by a feeling of 'community' in the trenches or not, has been exaggerated, but few deny altogether that it existed: Beckett, The Great War, 1914-1918, 218. Also, Hochschild, To End All Wars.

93 On Germany, see Bessel, Germany after the First World War. On Britain, see de Groot, Back in Blighty: The British at Home in World War One.

94 For opposing points of view, see Watson, Enduring the Great War; Fuller, Troop

Morale and Popular Culture; Rousseau, La Guerre censure: une histoire des

combattants européens.

95 Pick, War Machine, 136-270.

${ }^{96}$ Whalen, Bitter Wounds: German Victims of the Great War.

97 For instance, Hawkes, Ford Madox Ford and the Misfit Moderns.

${ }_{98}^{8}$ Blunden, Undertones of War, vii.

99 Wells, Mr Britling Sees It Through, 206.

${ }_{100}$ Watson, Experience, Memory, and the First World War, 185-296.

${ }^{101}$ Fraser, Robertshaw, and Roberts, Ghosts on the Somme; Reeves, "Cinema, Spectatorship and Propaganda," Historical Journal of Film, Radio and Television 17 (1997): 5-28; Badsey, "Battle of the Somme: British War-Propaganda," Historical Journal of Film, Radio and Television 3 (1983): 99-115; Reeves, Official British Film Propaganda during the First World War.

${ }^{102}$ Crompton, Shaw the Dramatist.

103 Oesterle, "Das Kriegserlebnis im für und wider. "Im Westen nichts Neues" von Erich

Maria Remarque," in van Laak (ed.), Literatur, die Geschichte schrieb, 213-23; Firda, All Quiet on the Western Front; Rüter, Erich Maria Remarque. Im Westen nichts Neues. Schneider, "The Truth about the War Finally," Journalism Studies 17 (2016): 498, gives a figure of 1.2 million sales in Germany by 1933 .

104 Winter, Sites of Memory, Sites of Mourning, 78-116. Andrew Frayn, Writing

Disenchantment, 22, 204, rightly points out 'the contention cannot hold' that 'there was a ten-year gap [after 1918] to realist prose about the war': nevertheless, 'while the tenyear distance from the war should not be conceived as a gap, it was a significant milestone'. Hugh Walpole had talked at the time - in a review of 1929 - of a 'period of silence' after the First World War.

105 Bruno Schultze, "Fiction and Truth: The Politics of the War Novel", in Stanzel and Löschnigg (eds.), Intimate Enemies, 297-311, has argued that the silence or delay was, at least in part, political rather than psychological. Virginia Woolf's Mrs Dalloway (1925) is a good example of a novel which alludes indirectly to the effects of war. Ford Madox Ford's Parade's End tetralogy (1924-8) is a classic historical saga. See Saunders, "Life Writing, Fiction and Modernism in British Narratives of the First World War," The RUSI Journal, 159 (2014), 106-11.

106 Frayn, Writing Disenchantment, 201-39; he pits his argument against that of Janet Watson, Fighting Different Wars, 186, who contends that it was 'only the difficulties of the 1920 s and after that created the disillusioned look back at war; it was not, for most people, a product of the war years themselves'. Cyril Falls, War Books (London, 1930), records that 22 war novels were published in 1929 and 15 in 1930, declining in number after that. No more than 8-9 are listed yearly between 1919 and 1928.

107 Linden, "Beyond Repetition: Karl Kraus's 'Absolute Satire'," German Studies Review 36 (2013): 515-36; Moorcroft Wilson, Siegfried Sassoon: The Journey from the 
Trenches; Johnson, "Realism and Satire: Siegfried Sassoon," in English Poetry of the First World War, 71-112.

${ }_{108}$ Fussell, The Great War and Modern Memory, 3-35.

109 Isherwood, "The British Publishing Industry and Commercial Memories of the First

World War," War in History 23 (2016): 332.

${ }^{110}$ Sassoon, The Complete Memoirs of George Sherston, 471.

${ }^{111}$ Ibid., 472.

112 Ibid., 229-30.

113 Ibid., 360-1.

114 Ibid., 425.

115 Mitchell, "Goodbye to All That: Robert Graves, Gerald Brenan and the Bloomsbury Set," London Magazine 32 (1992): 78-88. Some scholars have disputed this

interpretation, seeing Graves's post-war actions as a consequence of frustrations he experienced after 1918. To others, the final chapters seem deliberately desultory, emphasizing the drift of Graves's life, presented as an appendix.

116 Graves, Goodbye to All That, 60, 151. On the differences between autobiographical and fictional accounts in this context, see Cobley, "History and Ideology in

Autobiographical Literature of the First World War," Mosaic: A Journal for the Interdisciplinary Study of Literature 23 (1990): 37-54.

117 Graves, Goodbye to All That, 95.

${ }^{118}$ Ibid., 164.

119 Ibid., 238-79.

120 The aim was itself not universally accepted, of course, from its announcement by

Wells, The War that Will End War (New York, 1914) onwards. See Hochschild, To End All Wars; Gregory, The Last Great War: British Society and the First World War; Mulligan, The Great War for Peace, 48-222.

${ }^{121}$ Some historians have argued that anti-war writers were unrepresentative of soldiers themselves or of the subsequent post-war generation: Sheffield, Forgotten Victory: The First World War; Todman, The Great War: Myth and Memory; Bond, The Unquiet Western Front.

${ }_{122}$ Willis, Jr., "The Censored Language of War: Richard Aldington's Death of a Hero and Three Other War Novels," Twentieth Century Literature 45 (1999): 471-2.

${ }_{123}$ Im Westen nichts Neues was treated variously by critics as pacifist, anti-war or, even, pro-war: Schneider, “The Truth about the War Finally,” Journalism Studies 17 (2016): 490-501.

${ }^{124}$ For the reactions of the 'new right', see Breuer, Anatomie der Konservativen

Revolution, for further literature, which is extensive.

125 Eksteins, "All Quiet on the Western Front and the Fate of a War," Journal of

Contemporary History 15 (1980): 345-66.

${ }_{126}$ Remarque, All Quiet on the Western Front, 8-9, 72, 158, 199.

127 Ibid., 97.

${ }^{128}$ Figes, Crimea, 324-72; M. Hewitson, The People's Wars, 339-52, 392-409, 456-72.

129 Remarque, All Quiet on the Western Front, 147.

130 Ibid., 205.

${ }^{131}$ Ibid., 206.

132 Ibid., 207.

133 Schneider, “The Truth about the War Finally," Journalism Studies 17 (2016): 494.

134 Ibid., 496.

135 Ibid., 499. Zöberlein stressed, in opposition to Ullstein's publicity, that the archetype should not be an 'unknown soldier'.

${ }^{136}$ Jünger, The Storm of Steel, 9, 23, 25, 40, 250. 
137 Ibid., 109.

${ }^{138}$ Kiesel (ed.), Ernst Jünger. Kriegstagebuch, and B. Ziemann, Violence and the German Soldier in the Great War, 63-90.

139 Ibid., 316.

140 Ibid.

${ }^{141}$ Ibid., 316-17.

142 This is the impression he gives in In Stahlgewittern. His diary is another matter:

Ziemann, Violence and the German Soldier in the Great War, 88-90.

143 Aribert Reimann, Der große Krieg der Sprachen, 282, comes to this conclusion in respect of letters (and newspaper articles).

144 See Beaupré, "Soldier-Writers and Poets," in Winter (ed.), The Cambridge History of the First World War, vol. 3, 445-74; Schneider et al., Die Autoren und Bücher der deutschprachigen Literatur zum Ersten Weltkrieg.

145 T. Hardy, 'Apology to Late Lyrics and Earlier' (1922), quoted in Frayn, Writing Disenchantment, 8-9.

${ }^{146}$ D. H. Lawrence to J. B. Pinker, 5 Dec. 1914, ibid., 9.

147 On cross-over and continuing distinctions between diaries, memoirs, journalism and literature, see Tate, "The First World War: British Writing," in McLoughlin (ed.), The Cambridge Companion to War Writing, 160-74.

${ }^{148}$ Ian Isherwood, "The British Publishing Industry and Commercial Memories of the Great War," War in History 23 (2016): 328, has compiled a database of 350 books published between 1918 and 1939 but he admits that this is a work in progress.

149 Cobley, "History and Ideology in Autobiographical Literature of the First World War," Mosaic: A Journal for the Interdisciplinary Study of Literature, 23 (1990), 37.

150 Ibid., 46.

${ }^{151}$ Ibid., 45 .

${ }^{152}$ Johnston, "Realism and Satire: Siegfried Sassoon," in English Poetry of the First

World War, 71-111.

153 Linden, "Beyond Repetition," German Studies Review 36 (2013): 515-36.

154 Quoted in Frayn, Writing Disenchantment, 213-14.

155 Ibid., 213.

${ }^{156}$ Ibid. Also, Willis, Jr., “The Censored Language of War,” Twentieth-Century

Literature 45 (1999): 467-87.

157 Frayn, Writing Disenchantment, 219.

${ }^{158}$ Harari, The Ultimate Experience.

159 On Britain, see Monger, "Soldiers, Propaganda and Ideas of Home and Community in First World War Britain," Cultural and Social History 8 (2011): 331-54; Englander, "Soldiering and Identity," War in History 1 (1994): 300-318; Fuller, Troop Morale and Popular Culture; McCartney, Citizen Soldiers; Roper, The Secret Battle: Emotional Survival in the Great War. On Germany, see Watson, Enduring the Great War, and Ring of Steel, 160-329.

160 Bond, The Unquiet Western Front; Meyer, "The Tuition of Manhood," in Hammond and Towheed (eds.), Publishing in the First World War, 113-28; Cullen, "The Land of My Dreams: The Gendered Utopian Dreams and Disenchantment of British Literary ExCombatants of the Great War," Cultural and Social History 8 (2011): 195-211; Isherwood, "The British Publishing Industry and Commercial Memories of the First World War," War in History 23 (2016): 323-40; Bourke, Dismembering the Male: Men's Bodies, Britain and the Great War; J. S. K. Watson, Fighting Different Wars; R. M. Bracco, Merchants of Hope; H. Cecil, The Flower of Battle.

${ }^{161}$ Quoted in Frayn, Writing Disenchantment, 219. 
${ }_{162}$ Dugdale, Langemarck and Cambrai, in Isherwood, "The British Publishing Industry," War in History 23 (2016): 338.

163 Ibid., 340.

164 Ibid., 339-40.

165 Ibid., 336.

${ }^{166}$ Ibid., 332. See also Eksteins, "All Quiet on the Western Front and the Fate of a War," Journal of Contemporary History 15 (1980): 345-66.

167 Isherwood, “The British Publishing Industry,” War in History 23 (2016): 332.

168 Watson, Fighting Different Wars, 202.

${ }^{169}$ Eksteins, "All Quiet on the Western Front and the Fate of a War," Journal of

Contemporary History 15 (1980): 353.

170 Ibid.

${ }^{171}$ Eksteins, "War, Memory, and Politics," Central European History 13 (1980): 60-82.

172 Ibid., 72.

173 Ibid.

174 Ibid., 75-7.

175 Zuckmayer, Als wär's ein Stück von mir, 359-60.

${ }^{176}$ Kropp, Endlich Klarheit über Remarque und sein Buch 'Im Westen nichts Neues'.

177 Eksteins, "All Quiet on the Western Front and the Fate of a War," Journal of

Contemporary History 15 (1980): 348.

178 Ibid., 349.

179 Ibid., citing an interview given to Die literarische Welt on 14 June 1929. The argument here counters Eksteins's assertion that Remarque was guided most by the frustrations of the late 1920 .

${ }^{180}$ Schneider, “The Truth about the War Finally,” Journalism Studies 17 (2016): 497. 